\title{
Pengembangan Modul Terintegrasi Keislaman Materi Sistem Reproduksi Kelas IX SMP N 4 Katingan Kuala
}

\author{
Dewi Haryanti ${ }^{1 *}$, Nurul Septiana ${ }^{2}$, Nanik Lestariningsih ${ }^{3}$ \\ ${ }^{123}$ Program Studi Pendidikan Biologi IAIN Palangka Raya \\ E-mail: dewiharyanti040@gmail.com \\ diterima: 3 Maret 2020, disetujui: 7 Maret 2020, dipublikasikan: 30 Maret 2020
}

\begin{abstract}
This study aims to produce an Islamic learning module integrated with reproductive system material that has valid, practical and effective criteria so that the module can be used in learning and can improve student learning outcomes. This research used the Research \& Development method and was developed using the ADDIE model with Analyze stages, namely requirements analysis, Design which s the design / draft module, Development which is product development based on material validation, design validation, Islamic validation, small-scale trials, module revisions, Implementation ie the application of modules in large-scale trials of experimental classes (learning using modules), Evaluate is the final module. The results of this study indicated that the modules developed are suitable for use in learning science reproductive system material obtained from the validity value of material experts obtained from the value of $86.03 \%$ with valid criteria, design experts $82.44 \%$ valid, Islamic experts $85.52 \%$ valid. The practicality of using modules was obtained from observations of learning accomplishments of $98.65 \%$ with very successful criteria and the questionnaire responses of students showed a value with a percentage of $91.47 \%$ with the practical module category used. The effectiveness of the use of modules was obtained from an increase in student learning outcomes with $N$-Gain of 0.82 in the high category compared to the control class of an N-Gain of 0.29 with a low category. Thus, the learning modules developed were valid, practical, and effective for use in learning.
\end{abstract}

Keywords: development; Islamic integration; module.

\section{PENDAHULUAN}

Bahan ajar sangat penting digunakan peserta didik dan pendidik dalam kegiatan pembelajaran. Pendidik dan peserta didik akan mengalami kesulitan jika tanpa disertai bahan ajar dalam meningkatkan efektivitas pembelajarannya. Sehingga untuk meningkatkan kualitas pembelajran bahan ajar merupakan hal yang sangat penting untuk dikembangkan (Cahyoratri, 2018).

Salah satu bentuk bahan ajar yang dapat dikembangkan yakni adalah modul. Modul merupakan salah satu bentuk bahan ajar yang dibuat berdasarkan pengalaman belajar yang telah didesain dan direncanakan untuk membentuk peserta didik dalam mencapai tujuan pembelajaran (Daryanto, 2013). Berdasarkan uraian di atas bahan ajar merupakan hal sangat penting untuk dikembangkan karena dapat memudahkan pendidik dan peserta didik dalam proses pembelajarannya. Beberapa penelitian pengembangan modul ajar dalam pembelajaran biologi telah dilakukan dengan mengintegrasikan hasil penelitian dalam modul (Sulastri, Wiharti, Nugroho, 2019; Hartini, Hanik, Nugroho, 2019). 
Penelitian ini akan mengembangkan modul yang memiliki kelebihan dari modul lain, yakni modul terintegrasi keislaman yang bersumber Al-Qur'an dan Hadits. Modul diharapkan mampu menambah kualitas keimanan dan ketaqwaan peserta didik, dan menambah pengetahuan religius peserta didik yang tidak hanya mengacu pada ilmu sains saja tetapi juga ilmu yang mendasari Al-Qur'an dan hadits. Dengan adanya integrasi antara materi sistem reproduksi dengan ayat-ayat Al-Qur'an modul juga diharapkan mampu menstimulasi daya fikir kritis peserta didik tentang keterkaitan nilai keislaman dengan fakta-fakta sains yang ditemukan dalam kehidupan sehari-hari sehingga peserta didik tidak hanya menerima materi secara umumnya saja. Dengan demikian peserta didik akan memiliki pemahaman agama yang baik dan kokoh sehingga karakter yang baik akan terbentuk dalam diri peserta didik. Modul juga diharapkan dapat memberikan kontribusi yang baik terhadap peserta didik, yakni salah satunya lebih menjaga pergaulannya, dan membuat mereka menyadari tentang dampak buruk yang akan terjadi jika mereka tidak menjaga pergaulan dalam kehidupan seharihari. Pengintegrasian keislaman dalam modul juga bertujuan agar menumbuhkan sifat relegius peserta didik dan dapat dijadikan pedoman dalam belajar. Harapannya dengan menggunakan modul peserta didik mampu belajar tanpa ada yang mendampingi ketika mereka berada di dalam rumah, lebih memotivasi dalam belajar sehingga dapat meningkatkan hasil belajar peserta didik. Penggunaan modul ini juga diharapkan dapat meningkat keimanan peserta didik dalam belajar.

Hasil wawancara dengan salah satu guru IPA yang pada tanggal 25 Januari tahun
2019 bahwa di sekolah tersebut Guru belum pernah menggunakan modul berbasis nilainilai keislaman yang bersumber pada Alqur'an dan Hadits dalam proses pembelajaran, peserta didik hanya menggunakan buku penunjang dari sekolah, yang hanya dibagikan ketika proses pembelajaran di kelas saja, sehingga kesempatan peserta didik untuk mengulang materi pelajaran sangat sedikit. Buku penunjang tersebut sudah dilengkapi dengan gambar, tetapi gambarnya kurang menarik, karena umumnya gambar yang terdapat dalam buku masih hitam putih sehingga beberapa informasi pada gambar tidak terbaca. Dari hal tersebut menyebabkan informasi tidak tersampaikan secara jelas kepada peserta didik. Guru juga mengatakan di sekolah tersebut belum pernah menggunakan modul yang dikembangkan oleh guru sendiri. bahan ajar yang digunakan guru adalah buku paket saja, padahal pembelajaran menggunakan bahan ajar modul dapat menunjang peserta didik dalam meningkatkan kemampuan berpikir kritis. Sehingga peserta didik lebih aktif dalam mengikuti pembelajaran dan ilmu pengetahuan tidak berpusat pada guru saja. Selain itu diketahui juga hasil belajar peserta didik kelas IX dari tahun ke tahun tidak terdapat peningkatan khususnya pada materi sistem reproduksi dimana penguasaan materi peserta didik hanya mencapai $45 \%$ dengan nilai rata-rata dibawah 65 , sedangkan KKM yang ditetapkan adalah 70. Ditinjau dari permasalahan yang ada pada SMPN 4 katingan kuala maka peneliti tertarik untuk mengadakan penelitian yang berjudul "Pengembangan Modul Terintegrasi Keislaman Materi Sistem Reproduksi Kelas IX SMPN 4 Katingan Kuala”. 


\section{METODE PENELITIAN}

Jenis penelitian yang dilakukan adalah penelitian pengembangan atau Research and Development $(R \& D)$. Menurut Sugiyono dalam bukunya, metode penelitian dan pengembangan (dalam bahasa Inggris Research and Development) adalah metode penelitian yang digunakan untuk menghasilkan produk tertentu dan menguji keefektifan produk tersebut (Sugiyono, 2009 : 297). Penelitian ini menggunakan desain pembelajaran model ADDIE. Model ADDIE yaitu singkatan (Analyza, Desaign, Develop, Implemen, and Evluate). langkah-langkah yang ada dalam model pengembangan ADDIE, yaitu sebagai berikut :

Pada tahap analisis yang dilakukan adalah menganalisis perlunya pengembangan modul melalui analisis kebutuhan dan permasalahan yaitu berupa ketersediaan bahan ajar atau referensi yang mendukung kegiatan pembelajaran. Tahap selanjutnya yaitu desain, pada tahap ini dilakukannya pemilihan format, yaitu mendesain pemilihan pendekatan dan produk yang dikembangkan berdasarkan analisis kebutuhan dan merancang isntrumen yang digunakan untuk menilai modul terintegrasi keislaman. Pada tahap pengembangan, tahap ini merupakan tahap realisasi produk yang memiliki tujuan untuk menghasilkan modul yang layak secara teoritis. Pengembangan modul dilakukan sesuai dengan rancangan, selanjutnya modul akan divalidasi oleh ahli materi, dosen ahli media/desain, dan dosen ahli nilai keislaman. Pada proses validasi, validator menggunakan instrumen yang telah disusun sebelumnya. Dan Pada tahap ini peneliti juga melakukan analisis data terhadap hasil penelitian modul yang didapatkan dari validator, dengan tujuan memperoleh modul yang valid. Tahap selanjutnya yaitu penerapan, pada tahap ini, modul yang sudah valid diuji cobakan kepada skala kecil dan skala besar, tujuannya yaitu agar dapat menganalisis ketepatan perancangan atau desain pembelajaran, ketepatan isi bahan ajar. Pada tahap ini juga dilakukan penilaian yaitu dengan tes dan angket respon peserta didik. Tes digunkan untuk menilai keefektifan modul, sedangkan angket respon digunakan untuk menilai apakah modul tersebut praktis untuk digunakan. Tahap terakhir yaitu evaluasi, Pada tahap ini, peneliti melakukan revisi terakhir terhadap modul yang dikembangkan berdasarkan masukan yang diperoleh dari angket peserta didik, catatan observer dan para ahli.

Sumber data pada penelitian ini adalah berasal dari guru IPA dan peserta didik di sekolah SMPN 4 Katingan Kuala. Dan sumber data selanjutnya adalah pakar/ahli selaku validator modul.

Instrumen yang dilakukan dalam penelitian ini adalah (1) instrument untuk mengukur tingkat kevalidan berupa angket validitas para ahli; (2) instrument untuk mengukur kepraktisan berupa angket peserta didik dan lembar observasi lembar keterlaksanaan pembelajaran; (3) instrument untuk mengukur keefektivan yaitu menggunakan hasil tes belajar.

\section{HASIL DAN PEMBAHASAN}

Pada tahap analisis peneliti melakukan analisis melalui wawancara kepada guru dan peserta didik, hasil wawancara kepada guru dan peserta didik bahwa di sekolah tersebut belum pernah melakukan pembelajaran menggunakan modul terintegrasi keislaman. Pada saat analisis hasil belajar peserta didik kelas IX dari tahun ke tahun tidak terdapat peningkatan khususnya pada materi sistem 
reproduksi dimana penguasaan materi peserta didik hanya mencapai $45 \%$ dengan nilai rata-rata dibawah 65 , sedangkan KKM yang ditetapkan adalah 70. Peneliti mulai menyimpulkan permasalahan yang dihadapi selama pembelajaran sehingga perlu adanya pengembanga modul pembelajaran terintegrasi keislaman.

Design (rancangan). Ada beberapa hal yang dilakukan dalam tahap design produk pengembangan modul pembelajaran terintegrasi keislaman materi sistem reproduksi. Langkah-langkah penyusunan design produk modul ini, diantaranya adalah menyesuaikan kegiatan pembelajaran berdasarkan silabus/RPP.

Development

(Pengembangan).

Pengembangan modul dilakukan sesuai dengan rancangan, selanjutnya modul divalidasi. Validasi modul dilakukan oleh 6 dosen validator, yang terdiri dari 2 ahli materi, 2 ahli media / design, dan 2 ahli keislaman. Kriteria penentuan subyek ahli, yaitu : 1) berpengalaman dibidangnya, 2) berstatus sebagai dosen. Instrumen validasi menggunakan skala Likert. Adapun hasil validasi ahli materi seperti pada Tabel 1

Tabel 1 Validasi Ahli Materi

\begin{tabular}{|c|c|c|c|c|}
\hline \multirow[t]{3}{*}{ Aspek yang dinilai } & \multicolumn{4}{|c|}{ Validator Materi } \\
\hline & \multicolumn{2}{|c|}{$\mathrm{X}$} & \multicolumn{2}{|c|}{$\mathrm{Y}$} \\
\hline & Tahap & Tahap & Tahap & Tahap \\
\hline $\begin{array}{l}\text { Cakupan materi, } \\
\text { Keakuratan materi, } \\
\text { Kemutakhiran } \\
\text { materi, Mengandung } \\
\text { wawasan produktif, } \\
\text { Mendorong } \\
\text { keingintahuan, } \\
\text { Mengembangkan } \\
\text { kecakapan hidup, } \\
\text { Mengandung } \\
\text { wawasan } \\
\text { kontekstual }\end{array}$ & 61 & 64 & 51 & 58 \\
\hline Jumlah & \multicolumn{4}{|c|}{234} \\
\hline Persentase & \multicolumn{4}{|c|}{$86,03 \%$} \\
\hline Kriteria & \multicolumn{4}{|c|}{ Valid } \\
\hline
\end{tabular}

Berdasarkan nilai yang diberikan oleh validator, maka dilakukan revisi pada modul yang dikembangkan. Bagian yang direvisi sebagai berikut : 1) menambahkan pengetahuan awal tentang sistem reproduksi; 2) menambahkan materi tentang organ reproduksi dan memperbaiki isi LKPD; 3) menggunakan icon yang sesuai di dalam rangkuman; 4) menambahkan materi dikegiatan belajar yang membahas menstruasi, yakni tentang efek samping apabila haid tidak teratur; 5) menambahkan petunjuk dalam menjawab uji kompetensi disetiap kegiatan belajar; 6) memperbaiki tulisan-tulisan yang typo; 7) menambahkan referensi dari jurnal; 8) menambahkan jarak yang lebih luas di LKPD. Adapun hasil validasi ahli desain seperti pada Tabel 2.

Tabel 2. Validasi Ahli Desain

\begin{tabular}{|c|c|c|c|c|}
\hline \multirow[t]{4}{*}{ Aspek yang dinilai } & \multicolumn{4}{|c|}{ Validator Desain/Media } \\
\hline & \multicolumn{2}{|c|}{$X$} & \multicolumn{2}{|c|}{$\mathrm{Y}$} \\
\hline & Tahap & Tahap & Tahap & Tahap \\
\hline & 1 & 2 & 1 & 2 \\
\hline $\begin{array}{l}\text { Cakupan materi, } \\
\text { Keakuratan materi, } \\
\text { Kemutakhiran } \\
\text { materi, Mengandung } \\
\text { wawasan produktif, } \\
\text { Mendorong } \\
\text { keingintahuan, } \\
\text { Mengembangkan } \\
\text { kecakapan hidup, } \\
\text { Mengandung } \\
\text { wawasan kontekstual }\end{array}$ & 105 & 150 & 137 & 160 \\
\hline Jumlah & \multicolumn{4}{|c|}{552} \\
\hline Persentase & \multicolumn{4}{|c|}{$82,14 \%$} \\
\hline Kriteria & \multicolumn{4}{|c|}{ Valid } \\
\hline
\end{tabular}

Berdasarkan nilai yang diberikan oleh validator, maka dilakukan revisi pada modul yang dikembangkan. Bagian yang direvisi adalah sebagai berikut : 1) memperbaiki font dalam menulis tulisan arab; 2) memperbaiki desain cover; 3) memperbaiki spasi yang tidak kosisten; 4) memperbaiki warna gambar. Adapun hasil validasi ahli keislaman seperti pada Tabel 3. 
Tabel 3 Validasi Ahli Keislaman

\begin{tabular}{|c|c|c|c|c|}
\hline \multirow[t]{3}{*}{ Aspek Yang Dinilai } & \multicolumn{4}{|c|}{ Validator Integrasi Keislaman } \\
\hline & \multicolumn{2}{|c|}{$\mathrm{X}$} & \multicolumn{2}{|c|}{$\mathrm{Y}$} \\
\hline & $\begin{array}{l}\text { Tahap } 1 \\
\end{array}$ & Tahap 2 & Tahap 1 & $\begin{array}{c}\text { Tahap } \\
2\end{array}$ \\
\hline $\begin{array}{ll}\text { Kesesuaian } & \\
\text { Penulisan Integrasi } \\
\text { Keislaman }\end{array}$ & 60 & 71 & 63 & 66 \\
\hline Jumlah & \multicolumn{4}{|c|}{260} \\
\hline Persentase & \multicolumn{4}{|c|}{$85,52 \%$} \\
\hline Kriteria & \multicolumn{4}{|c|}{ Valid } \\
\hline
\end{tabular}

Berdasarkan nilai yang diberikan oleh validator, maka dilakukan revisi pada modul yang dikembangkan. Bagian yang direvisi adalah sebagai berikut : 1) menambah referensi terkait dari Al-Qur'an dan hadits; 2) menambahkan manfaat penggunaan modul bagi kehidupan sehari-hari yang dikaitkan dengan nilai keIslaman; 3) menambahkan instruksi untuk dibaca bersama-sama bacaan yang bersumber pada Al-Qur'an dan hadits./ untuk menguji kemenarikan/ kelayakan produk serta peningkatan hasil belajar pengguna modul dengan jumlah yang dibatasi. Pada uji coba skala kecil rata-rata nilai pretest mencapai skor 38,41 dan pada posttest mencapai nilai 87,30. Dilihat dari nilai tersebut maka pembelajaran dikatakan berhasil karena terdapat peningkatan hasil belajar.

Setelah melakukan uji coba skala kecil, dan tidak terdapat revisi kemudia produk masuk ketahap implementasi. Implementasi dilakukan disekolah SMPN 4 Katingan Kuala yang ditunjuk sebagai tempat penelitian. Implementasi pada uji coba skala besar terdiri dari 20 peserta didik dari kelas kontrol dan 20 peserta didik kelas eksperimen. Pada kelas kontrol nilai ratarata pretest mencapai 39,29 dan rata-rata posttest mencapai 57,57. Sedangkan pada kelas eksperimen (menggunakan modul) hasil belajar peserta didik mendapatkan nilai rata-rata pretest mencapai 39 dan rata-rata posttest mencapai 89 . Data N-Gain diperoleh dari hasil pretest dan postest, nilai $\mathrm{N}$-gain dihitung untuk mengetahui peningkatan hasil belajar peserta didik pada uji skala besar (kontrol dan eksperimen) seperti yang disajikan pada Tabel 4

Tabel 4 N-Gain Kelas Kontrol dan Kelas Eksperimen

\begin{tabular}{cccc}
\hline \multicolumn{2}{c}{ Kelas Kontrol } & \multicolumn{2}{c}{ Kelas Eksperimen } \\
\hline Rata-rata & Kategori & Rata-rata & Kategori \\
\hline 0,29 & Rendah & 0,82 & Tinggi \\
\hline
\end{tabular}

Selama kegiatan berlangsung, keterlaksanaan/keterterapan pembelajaran menggunakan modul terintegrasi keislaman diamati oleh observer. Observer pada penelitian ini berjumlah 4 orang, masingmasing observer mengamati kemandirian 5 orang peserta didik yang berada dikelas eksperimen ketika proses pembelajaran dilakukan. Hasil akhir keterlaksanaan menggunakan modul mencapai nilai dengan presentase $98,65 \%$ dengan kriteria sangat berhasil.

Modul yang dikembangkan praktis atau mudah dipahami dapat diketahui melalui angket respon peserta didik. Angket ini diisi oleh peserta didik setelah mereka selesai melakukan proses pembelajaran menggunakan modul terintegrasi keislaman. Hasil respon peserta didik pada kelas skala kecil menunjukkan hasil akhir dengan persentase $88,38 \%$ dengan kriteria praktis, sedangkan pada kelas skala ekperimen menunjukkan hasil akhir 91,47\% dengan kriteria sangat praktis.

Evaluate (Evaluasi). Tahap evaluasi merupakan tahap terakhir dalam model ADDIE. Evaluasi dilakukan untuk menganalisis data kevalidan modul, kepraktisan dan keefektivan modul yang dikembangkan. Pada tahap ini, peneliti 
melakukan revisi terakhir terhadap modul yang dikembangkan berdasarkan masukan yang diperoleh dari angket respon dan catatan lapangan pada lembar observasi. Hal ini bertujuan agar modul yang dikembangkan benar-benar sesuai dan dapat digunakan pada mata pelajaran IPA materi sistem reproduksi.

Berdasarkan penilaian dan saran oleh pakar beserta peserta didik maka dihasilkan modul terintegrasi keislaman materi sistem reproduksi kelas IX dengan profil akhir yaitu : (1) sampul/cover, (2) kata pengantar, (3) peta konsep, (4) pendahuluan, (5) daftar isi, (6) kegiatan belajar ( terdiri dari 3 kegiatan belajar), (7) glosarium, (8) daftar pustaka.

Validitas modul ini dilakukan oleh ahli materi, ahli media dan ahli keislaman. Dari penilaian para ahli tersebut diperoleh kelayakan modul terintegrasi keislaman materi sistem reproduksi kelas IX. Hasil penelitian dinyatakan valid oleh validator materi dengan presentase 86,03\% karena materi sistem reproduksi yang diterangkan pada modul telah sesuai dan telah mengacu kepada kurikulum, dan materi yang telah dijabarkan di dalam modul telah sesuai dengan indikator pembelajaran yang telah tercantum pada RPP. Hasil penelitian juga dinyatakan valid oleh ahli media dengan persentase $82,44 \%$ karena modul memuat aspek media meliputi kejelasan petunjuk penggunaan modul, keterbacaan teks/huruf, kualitas tampilan gambar, penggunaan gambar yang menarik,pemilihan margin yang tepat, dan pemilihan warna gambar yang sesuai dengan background. Hasil penelitian juga dinyatakan valid oleh ahli keislaman dengan persentase $85,52 \%$ karena di dalam modul memuat kesesuaian hubungan ayatayat Al-Qur'an dan hadits dengan materi. Menurut Baharudin (2012) modul dinyatakan valid menurut ahli keislaman jika di dalam modul tersebut memiliki kesesuaian antara dalil-dalil yang digunakan dengan materi. Berdasarkan kesimpulah oleh beberapa validator menyatakan bahwa modul pembelajaran terintegrasi keislaman materi sistem reproduksi layak dan dapat diuji cobakan.

Kepraktisan dalam penelitian ini menggunakan angket respon peserta didik dan respon observer pada saat uji lapangan. Angket respon peserta didik digunakan untuk mengetahui tanggapan pengguna dan tingkat kepraktisan modul yang dikembangkan, sedangkan lembar observasi digunakan untuk mengetahui keterlaksanaan pembelajaran menggunakan modul yang dikembangkan. Hasil penelitian dilihat dari respon peserta didik pada kelas skala kecil dan kelas eksperimen. Respon peserta didik pada skala kecil menunjukan hasil akhir dengan persentase 88,38 dengan kriteria praktis, sedangkan respon peserta didik pada skala besar menunjukkan hasil akhir dengan persentase 91,47 dengan kriteria sangat praktis. Hasil observasi yang dilakukan oleh 4 observer menunjukkan hasil akhir dengan presentase $98,65 \%$ dengan kategori sangat berhasil. Modul pembelajaran yang dikembangkan praktis dan berhasil untuk digunakan dalam pembelajaran. Hal ini didukung oleh Setiyadi (2017) yang menyatakan bahwa keterlaksanaan pembelajaran yang baik adalah jika derajat keterlaksanaan pembelajaran yang dicapai tersebut minimal berkategori tinggi atau baik.

Keefektifan suatu modul menurut (Rizqi, 2013) dapat dilihat pada beberapa komponen salah satunya dari hasil belajar peserta didik yang dapat mencapai ketuntasan atau melebihi KKM. Hal ini sejalan dengan (Firman 2018) peningkatan hasil belajar dapat dilihat dari perbedaan 
hasil belajar yang signifikan dari rata-rata nilai postest kelas eksperimen dan kelas kontrol. Berdasarkan hasil penelitian terdapat perbedaan peningkatan hasil belajar peserta didik menggunakan modul pembelajaran dan peserta didik tanpa menggunakan modul pembelajaran. Perolehan nilai rata-rata peserta didik yang belajar menggunakan modul pembelajaran pada skala kecil dengan rata-rata sebesar 87,30 dengan kategori sangat baik, kemudian hasil belajar peserta didik pada kelas eksperimen (menggunakan modul) mencapai nilai dengan rata-rata 89 dengan kategori sangat baik. Sedangkan pada kelas kontrol (tanpa menggunakan modul) mencapai nilai dengan rata-rata 57,57 dengan kategori cukup baik.

Perbandingan nilai rata-rata pretest dan postest kelas eksperimen dan kontrol dapat dilihat dari data analisis nilai normalitas gain (N-Gain). Rata-rata nilai $\mathrm{N}$ Gain kelas kontrol sebesar 0,29 dengan kategori rendah. Sedangkan rata-rata nilai $\mathrm{N}$ Gain kelas eksperimen 0,82 dengan kategori tinggi. Berdasarkan hasil perhitungan N-Gain yang telah didapat maka dapat disimpulkan bahwa modul terintegrasi keislaman materi sistem reproduksi efektif atau dapat meningkatkan hasil belajar peserta didik. Hasil penelitian lain tentang penerapan modul dalam pembelajaran biologi juga efektif dalam memberdayakan kemampuan berpikir (Nugroho, 2018).

\section{KESIMPULAN}

Modul dinyatakan valid oleh validator materi dengan presentase $86,03 \%$ karena materi sistem reproduksi yang diterangkan pada modul telah sesuai dan telah mengacu kepada kurikulum, dan materi yang telah. Modul dinyatakan valid oleh ahli media dengan persentase 82,14 \% karena modul memuat aspek media meliputi kejelasan petunjuk penggunaan modul, keterbacaan teks/huruf, kualitas tampilan gambar, penggunaan gambar yang menarik, pemilihan margin yang tepat, dan pemilihan warna gambar yang sesuai dengan background. Modul dinyatakan vali oleh ahli keislaman dengan persentase 82,56\% karena di dalam modul memuat kesesuaian hubungan ayatayat Al-Qur'an dan hadits dengan materi. Modul dinyatakan praktis berdasarkan penilaian keterlaksanaan pembelajaran yang diamati oleh observer yakni terlaksana dengan sangat baik dengan nilai karena peserta didik terlibat aktif dalam pembelajaran. Modul juga dinyatakan praktis berdasarkan respons positif peserta didik dengan persentase ditinjau dari tingkat kemudahanpeserta didik dalam menggunakannya. Modul dinyatakan efektif dilihat dari ketuntasan dan peningkatan hasil belajar peserta didik yakni rata-rata postest kelas eksperimen.

\section{UCAPAN TERIMA KASIH}

Penulis mengucapkan terima kasih kepada semua pihak yang telah membantu dalam penelitian dan penulisan artikel ini.

\section{DAFTAR PUSTAKA}

Baharuddin. (2012). Pengembangan Sumber Belajar Berbasis Multimedia Interaktif. Jurnal Teknologi Pendidikan,2(1), 55-56.

Cahyoratri. (2018). Jurnal Biologi Pengembangan Modul berbasis POP Materi Virus Kelas X SMA.Halaman 2.

Daryanto. (2013). Menyusun Modul Bahan Ajar untuk Persiapan Guru dalam Mengajar. Yogyakarta : Gava Media.

Firman. (2018). Efektivitas Pendekatan Saintifik untuk Meningkatkan Hasil Belajar Siswa. Jurnal Forum Ilmu Sosial, 45(1), 1-9

Hartini, H., Hanik, N. R., \& Nugroho, A. A. (2019). Keanekaragaman dan Kemelimpahan Serangga di Hutan Bromo Karangannyar 


\section{Journal of Biology Learning}

Volume 2, Issue 1, page 33 - 40, March2020

Sebagai Sumber Alternatif Belajar Biologi di SMA. Journal of Biology Learning, 1(1).

Nugroho, A. A. (2018, October). Keefektifan Penggunaan Modul Biologi Molekuler Berbasis Learning Cycle 7E untuk Memberdayakan Kemampuan Berpikir Mahasiswa. In Proceeding Biology Education Conference: Biology, Science, Enviromental, and Learning (Vol. 15, No. 1, pp. 620-626).

Rizqi. (2013). Pengembangan Modul IPA Terpadu Berkarakter Tema Pemanasan Global untuk Siswa SMP/Mts. Unnes Science Education Journal, 2(1), 89-90.

Sahlan. (2012). Desain Pembelajaran Berbasis Pendidikan Karakter. Yogyakarta :Ar-ruzz Media.

Setiyadi, M. W, Ismail, Hamsu, A.G. (2017). Pengembangan modul pembelajaran biologi berbasis pendekatan saintifik untuk meningkatkan hasil belajar siswa. Journal of Educational Science and Technology (EST), 3(2), 102-112.

Sulastri, S., Wiharti, T., \& Nugroho, A. A. (2019). Keanekaragaman Tumbuhan Paku di Kawasan Wisata Alam Candi Muncar Wonogiri Sebagai Bahan Penyusunan Modul Pembelajaran. Journal of Biology Learning, 1(1). 